\title{
The chemistry of tryptanthrin and its derivatives
}

\author{
Ashli M. Tucker and Peter Grundt* \\ Department of Chemistry and Biochemistry, University of Minnesota Duluth, \\ 1039 University Drive, Duluth, MN 55812, USA \\ E-mail:pgrundt@d.umn.edu
}

\begin{abstract}
Tryptanthrin (indolo[2,1-b]quinazoline-6,12-dione) is a natural product which shows significant biological activity as an antibacterial, antiparasitic, and antineoplastic agent. Historically, tryptanthrin has been found as a component of many dyes as well as a constituent of medicinal herbal treatments. This review describes the synthesis of tryptanthrin and some related compounds which also have a quinazoline ring fused to an indolo moiety as a core.
\end{abstract}

Keywords: Tryptanthrin, indoles fused, quinazolines fused, alkaloids

\section{Table of Contents}

1. Introduction

2. Synthesis

2.1 Construction of the quinazoline system

2.2 Construction of the indole system

3. Selected reactions of tryptanthrin and its derivatives

3.1. Aromatic substitution reactions

3.1.1 Electrophilic aromatic substitution

3.1.2. Nucleophilic aromatic substitution

3.2. Reactions involving the carbonyl groups

3.2.1 Hydrolysis

3.2.2 Reduction

3.2.3 Oxidation

3.2.4 Reactions with nitrogen nucleophiles

3.2.5 Reactions with $\mathrm{CH}$-acidic compounds

3.2.6. Reactions with Grignard reagents

3.2.7 Synthesis of 6-spiro derivatives

4. References 


\section{Introduction}

The natural product tryptanthrin (indolo[2,1-b]quinazoline-6,12-dione, Figure 1) is a weakly basic alkaloid. This bright yellow compound consists of a quinazoline ring fused to an indole moiety with carbonyl groups in the 6- and 12-positions. The name tryptanthrin is derived from the observation that this compound is produced by the yeast Candida lipolytica when grown in L-tryptophan-containing medium. ${ }^{1}$ Occasionally the alternative spelling tryptanthrine is used to describe this compound. Chemical Abstracts appear to index both spellings.

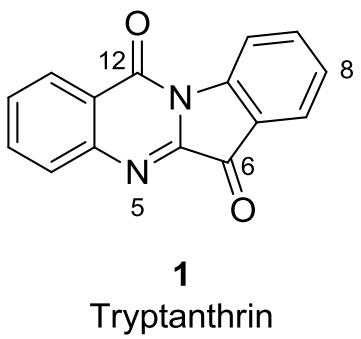

\section{Figure 1}

This review describes the synthesis of compounds with a tryptanthrin core and selected reactions of this class of compounds. ${ }^{2}$ Tryptanthrin and its derivatives are of particular interest due to their biological activities. Tryptanthrin compounds have been shown to possess antibacterial $^{3}$, antiparasitic ${ }^{4}$, and antineoplastic ${ }^{5,6}$ properties. Extensive work has been put forth to elucidate the usefulness of tryptanthrin derivatives as dyes and pigments and as photoelectric materials. ${ }^{7,8}$ The physicochemical properties of tryptanthrin compounds deposited onto surfaces have also been investigated. ${ }^{9}$

In 1892 O'Neil described the formation of "silky golden-yellow crystals" that form upon oxidation of indigo with potassium permanganate. ${ }^{10,11}$ In 1915 Friedländer and Roschdestwensky were able to elucidate the structure of tryptanthrin, ${ }^{12}$ which was verified 60 years later by X-ray crystallography. ${ }^{13}$

Tryptanthrin has been isolated from numerous natural sources. In particular, tryptanthrin is found in plant material traditionally used as colorants including Chinese woad (Isatis tinctoria), ${ }^{14,15}$ Japanese indigo (Polygonum tinctorium), ${ }^{14,16}$ Assam indigo (Strobilanthes cusia), ${ }^{17}$ Indigo naturalis (Strobilanthes formosanus), ${ }^{18}$ and dyer's oleander (Wrightia tinctoria). ${ }^{19}$ Furthermore tryptanthrin has also been isolated from the fruits of the cannonball tree (Couroupita guaianensis), ${ }^{20,21}$ the orchids Phaius mishmensis ${ }^{22}$ and Calanthe discolor, ${ }^{23}$ and the fungi Schizophyllum commune and Leucopaxillus cerealis, ${ }^{24,25}$ and a strain of the bacterial Cytophaga genus. ${ }^{26}$ Tryptanthrin has also been found in mammals, specifically in the urine of the Asian elephant (Elephas maximus) ${ }^{27}$ and the wing sac liquids of the bat Saccopteryx bilineata. ${ }^{28}$

Several compounds have been observed in nature with an indolo[2,1-b]quinazoline core in which the keto group in 6-position has been replaced with a different functional group (Figure 2). 
In particular the orchid Phaius mishmensis was reported to be a rich source of such compounds. ${ }^{22}$ Tryptanthrin derivatives 2-7 have all been isolated from this plant. Candidine (qingdainone, 6) a tryptanthrin based compound substituted with an additional indolo ring at the 6-position, has also been found in the Chinese herbal medicine qing dai, ${ }^{29}$ Chinese woad ${ }^{30}$ and in the fruits of the cannonball tree. ${ }^{20,21}$ In humans, uremic patients appear to form candidine (6) in very small amounts since this compound has been isolated from blood plasma, urine and haemofiltrate of such individuals. ${ }^{31}$ Bergman et al. have reported that $\mathbf{6}$ is also a minor product that is formed together with tryptanthrin upon digestion of L-tryptophan by the yeast Candida lipolytica. ${ }^{32}$ Methylisatoid (7) is the only 12-position modified tryptanthrin compound observed in nature. ${ }^{22}$ Tryptanthrin compounds bearing substituents on the aromatic rings appear to be scarce in nature. Only a few examples have been observed, including phaitanthrin C (8) also isolated from Phaius mishmensis $^{22}$ and ophiuroidine, $(\mathbf{9})$ found in the brittle star Ophiocoma riisei ${ }^{33}$<smiles>CC(=O)CC1(O)c2ccccc2-n2c1nc1ccccc1c2=O</smiles>

2 (Phaitanthrin A)<smiles>O=C1/C(=c2\c3ccccc3n3c(=O)c4ccccc4nc23)Nc2ccccc21</smiles>

6

(Candidine, Qingdainone)<smiles>COC(=O)CC1(O)c2ccccc2-n2c1nc1ccccc1c2=O</smiles>

3 (Phaitanthrin B)<smiles>COC(=O)C1(O)c2ccccc2N=C2C(=O)c3ccccc3N21</smiles>

7 (Methylisatoid)<smiles>O=C1OCC23Nc4ccccc4C(=O)N2c2ccccc2C13</smiles>

4 (Phaitanthrin D)<smiles>O=C1c2c(O)cccc2-n2c1nc1ccccc1c2=O</smiles>

8 (Phaitanthrin C)<smiles>COC(=O)c1c2ccccc2n2c(=O)c3ccccc3[nH]c12</smiles>

5

(Phaitanthrin E)

Figure 2

\section{Synthesis}

\subsection{Construction of the quinazoline system}

One common approach for the synthesis of tryptanthrin is the construction of the quinazoline system as the final key step. The starting materials for these procedures are derivatives of 
anthranilic acid (10) in particular isatoic anhydride, which reacts with compounds containing an indole core (11) - in particular isatin or oxindole (Scheme 1). During the cyclization, bond formation occurs between N-5 and C-5a as well as N-11 and C-12<smiles>[X]C(=O)c1ccccc1N</smiles>

10

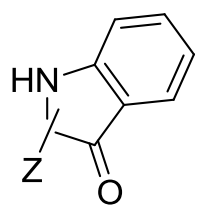

11

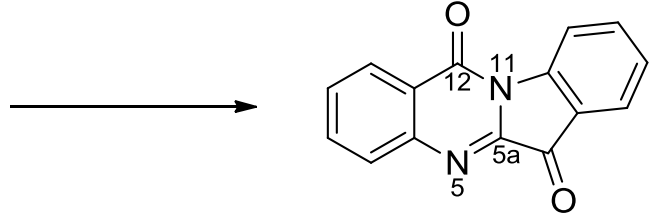

1

\section{Scheme 1}

The most efficient method for the synthesis of tryptanthrin and many of its analogues is the reaction of isatoic anhydride (12) with isatin (13, Scheme 2). ${ }^{6-8,25,34-45}$ This procedure has economic advantages, as many of the isatin and isatoic anhydride reactants are commercially available or can be easily synthesized by well established procedures.<smiles>O=c1[nH]c2ccccc2c(=O)o1</smiles>

12

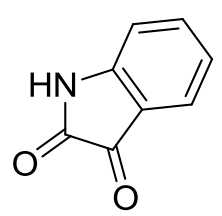

13<smiles>O=C1c2ccccc2-n2c1nc1ccccc1c2=O</smiles>

1

\section{Scheme 2}

Numerous reaction conditions have been developed to accomplish this transformation. The experimentally simplest methods involve heating $\mathbf{1 2}$ and $\mathbf{1 3}$ in a solvent such as toluene in the presence of triethylamine or pyridine. ${ }^{6,21}$ Alternative reactions conditions involve DBU/DMAP or an inorganic base such as a sodium hydride/DMF ${ }^{37-40}$ or sodium hydroxide/dioxane. ${ }^{41} \mathrm{~A}$ solvent-free protocol under microwave conditions in the presence of potassium carbonate has also been reported. ${ }^{42}$

Excess isatoic anhydride has been found useful to catalyze the synthesis by scavenging any developing water. ${ }^{42}$ The addition of diisopropyl carbodiimide, dicyclohexylcarbodiimide, or 1,1'carbonyldiimidazole/pyridine has also been employed for this purpose. ${ }^{34-36,44}$ Interestingly, in the presence of $\beta$-cyclodextrin this procedure also works using water as a solvent. ${ }^{43}$

Formation of tryptanthrin also occurs during the oxidation of indigo (14), which can be explained by the presence of isatoic anhydride (12) and isatin (13) in the reaction mixture. A more recent example of indigo oxidation to tryptanthrin using ozone as the oxidant is shown in 
Scheme $3 .{ }^{46}$ Under the reaction conditions the central double bond (C2-C2'-bond) of indigo (14) is cleaved to form isatin (13) as a primary oxidation product. Some isatin will then undergo further oxidation resulting in isatoic anhydride (12). Finally, condensation of these two oxidation products yielded tryptanthrin. The yields of tryptanthrin as an indigo oxidation byproduct are generally low. ${ }^{46,47}$<smiles>O=C1C(=C2Nc3ccccc3C2=O)Nc2ccccc21</smiles>

14

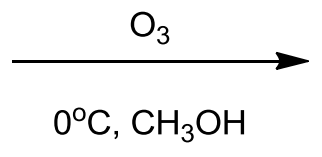

$0^{\circ} \mathrm{C}, \mathrm{CH}_{3} \mathrm{OH}$<smiles>O=C1Nc2ccccc2C1=O</smiles>

12 13

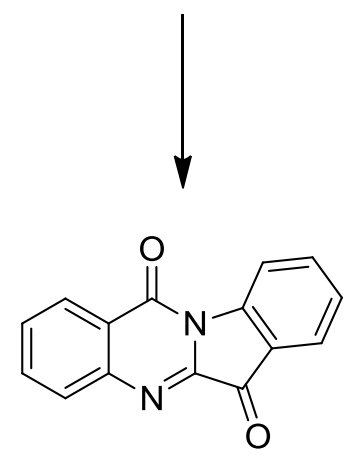

1

\section{Scheme 3}

Several alternative means of synthesis have been developed that do not require isatoic anhydride. Recently, Jahng et al. described a one-pot synthesis of tryptanthrin using anthranilic acid (15, Scheme 4) as starting material. ${ }^{48}$ In this method 15 reacts with thionyl chloride to form a thio-analog of isatoic anhydride (16), which then condenses with isatin (13) to form tryptanthrin in excellent yield.<smiles>Nc1ccccc1C(=O)O</smiles>

15

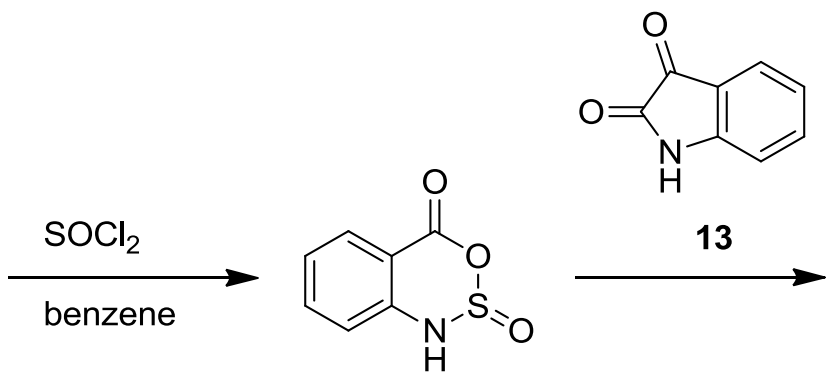

16<smiles>O=C1c2ccccc2-n2c1nc1ccccc1c2=O</smiles>

$1(85 \%)$

\section{Scheme 4}


Eguchi et al. investigated the preparation of tryptanthrin from 2-azidobenzoyl chloride (17) with an intramolecular aza-Wittig reaction as the key step (Scheme 5). ${ }^{49}$ In this one-pot procedure 17 was reacted with isatin (13) to give the corresponding amide 18, which in the presence tributylphosphine formed the iminophosphorane (19). Subsequent cyclization gave tryptanthrin in $43 \%$ yield.<smiles>Nc1ccccc1C(=O)Cl</smiles>

17<smiles>O=C1Nc2ccccc2C1=O</smiles>

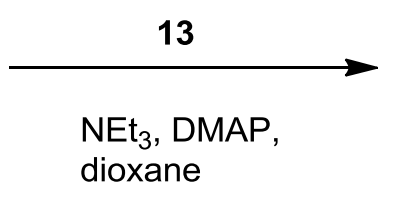<smiles>Nc1ccccc1C(=O)N1C(=O)C(=O)c2ccccc21</smiles>

18

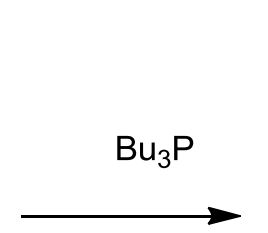

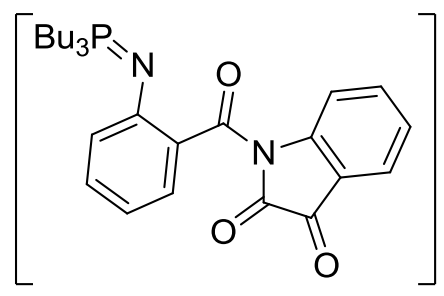

19<smiles>O=C1c2ccccc2-n2c1nc1ccccc1c2=O</smiles>

$1(43 \%)$

\section{Scheme 5}

Bergman et al. $^{36}$ approached the synthesis of tryptanthrin by using chloroindoleninone compound $\mathbf{2 0}$ as the indole core component (Scheme 6). For this procedure isatin (13) was treated with phosphoryl chloride to form $\mathbf{2 0}{ }^{50}$ Further reaction of $\mathbf{2 0}$ with anthranilamide (21) produced tryptanthrin in excellent yield.<smiles>O=C1Nc2ccccc2C1=O</smiles>

13

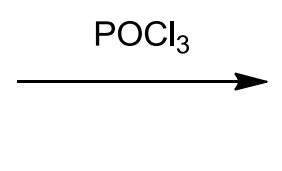<smiles>O=C1C(Cl)=Nc2ccccc21</smiles>

20<smiles>NC(=O)c1ccccc1N</smiles>

21<smiles>O=C1C(Cl)=Nc2ccccc21</smiles>

20

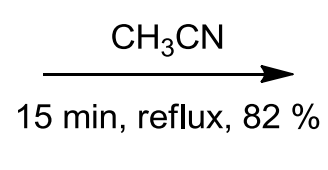<smiles>O=C1c2ccccc2-n2c1nc1ccccc1c2=O</smiles>

1

\section{Scheme 6}


Moskovkina developed a similar technique. ${ }^{51}$ However, after chloroindoline (20) had been formed, instead of adding an anthranilic acid derivative such as compound $\mathbf{2 1}$ excess of isatin (13) was used as its equivalent. In this modification compound 20 was generated in situ and condensed with the isatin. This procedure has been used to synthesize a perdeuterated derivative of tryptanthrin (Scheme 7). ${ }^{52}$<smiles>[2H]c1c([2H])c([2H])c2c(c1[2H])NC(=O)C2=O</smiles>

22<smiles>[2H]c1c([2H])c([2H])c2c(c1[2H])N=C(Cl)C2=O</smiles>

23 (generated in situ)

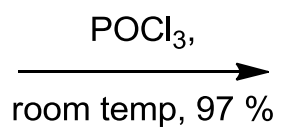<smiles>[2H]c1c([2H])c([2H])c2c(c1[2H])C(=O)c1nc3c([2H])c([2H])c([2H])c([2H])c3n1C2=O</smiles>

24

\section{Scheme 7}

Dimerization of isatin has also been achieved electrochemically ${ }^{53}$, by radiation with laser light ${ }^{54}$ or in the presence of an oxidizing agent such as potassium permanganate. ${ }^{29}$ The yields of these reactions are generally low. Closely related is the oxidative dimerization of 3 -indole compounds. During the oxidation of the 5-bromo-3-acetoxyindole (25) with oxone the 2,8dibromo derivative of tryptanthrin (26) was observed as a minor product (Scheme 8). ${ }^{55}$<smiles>CC(=O)Oc1c[nH]c2ccc(Br)cc12</smiles>

25

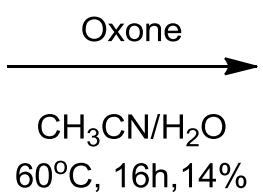

$60^{\circ} \mathrm{C}, 16 \mathrm{~h}, 14 \%$<smiles>O=C1c2cc(Br)ccc2-n2c1nc1ccc(Br)cc1c2=O</smiles>

26

\section{Scheme 8}

In a different approach tryptanthrin was prepared by the reaction of 2-aminobenzaldehyde (27) with $O$-methylisatin (28) resulting in the formation of dihydro tryptanthrin analog (29) in excellent yield (Scheme 9). ${ }^{56}$ Oxidation of $\mathbf{2 9}$ with $\mathrm{CrO}_{3}$ at room temperature gave tryptanthrin.

An alternative procedure for the synthesis of tryptanthrin was developed by Jahng et al. and used oxindole hydrochloride (30) and methyl anthranilate as starting materials (Scheme 10). ${ }^{57}$ Upon treatment with phosphoryl chloride these two compound reacted to form the key intermediate 32. Further conversion of the $\mathbf{3 2}$ lead to the 6-benzylidene derivative 34, which was subjected to ozonolysis to give tryptanthrin. The key intermediate $\mathbf{3 2}$ is also known predominantly to yield tryptanthrin upon exposure to air. ${ }^{56,58,59}$ 


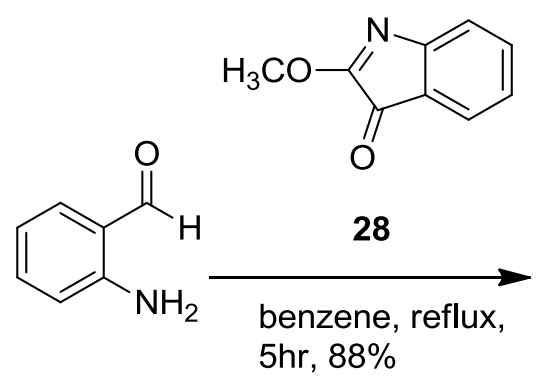

27

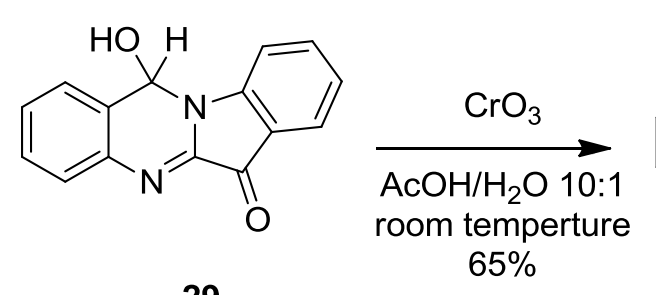

29<smiles>O=C1c2ccccc2-n2c1nc1ccccc1c2=O</smiles>

\section{Scheme 9}<smiles>O=C1Cc2ccccc2N1</smiles>

30<smiles>O=Cc1ccccc1</smiles>
$\underset{\substack{\mathrm{Ac}_{2} \mathrm{O}, \text { reflux, } \\ 89 \%}}{\stackrel{33 \mathrm{~h},}{\longrightarrow}}$<smiles>O=c1c2ccccc2nc2/c(=C/c3ccccc3)c3ccccc3n12</smiles>

34<smiles>COC(=O)c1ccccc1N</smiles>
$12 \mathrm{~h}, 82 \%$

32

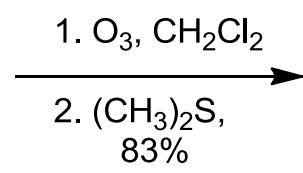
$83 \%$<smiles>O=C1c2ccccc2-n2c1nc1ccccc1c2=O</smiles>

1

\section{Scheme 10}

Kikumoto and Kobayashi prepared tryptanthrin by reductive N-heterocyclization (Scheme 11). ${ }^{60}$ In this procedure 2-nitrobenzoic acid (36) was converted into the corresponding 1-benzoyl isatin compound 37. Reductive intramolecular cyclization of $\mathbf{3 7}$ induced by tin(II) chloride gave tryptanthrin an $85 \%$ yield over two steps. 
<smiles>O=C(O)c1ccccc1[N+](=O)[O-]</smiles>

\section{Scheme 11}

Akazome et al. used a slightly different approach to accomplish the cyclization step of the above sequence to produce tryptanthrin. Intermediate $\mathbf{3 7}$ was treated with a catalytic amount of triruthenium dodecacarbonyl $\left(\mathrm{Ru}_{3}(\mathrm{CO})_{12}\right)$ in a carbon monoxide atmosphere under vigorous conditions $\left(140^{\circ} \mathrm{C}, 40 \mathrm{~kg} / \mathrm{cm}^{-2}(\sim 39 \mathrm{~atm}) \mathrm{CO}\right.$ pressure, $\left.16 \mathrm{~h}\right){ }^{45}$ The yield (46\%) for this transition metal catalyzed procedure was significantly lower than that reported by Kikumoto et al.

Zeide and Chelintsev ${ }^{61}$ have reported a two step procedure that produced tryptanthrin in $62 \%$ overall yield (Scheme 12). This sequence significantly differs from any other approach outlined above because it does not involve isatin or oxindole precursors. The first step in this sequence involved a nucleophilic substitution of the 2-chloro-group in 2-chloroquinoline (38) by the amino group of anthranilic acid (15). An overall loss of water lead to the intermediate (39). In the second step of the reaction sequence, potassium permanganate induced an oxidative ring contraction to give tryptanthrin.<smiles>Nc1ccccc1C(=O)O</smiles>

15

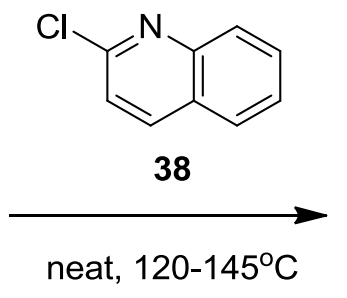

$95 \%$

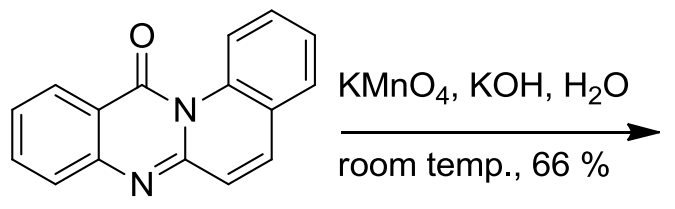

39<smiles>O=C1c2ccccc2-n2c1nc1ccccc1c2=O</smiles>

1

\section{Scheme 12}

\subsection{Construction of the indole system}

Only a few synthetic approaches for tryptanthrin center on the bond formation within the indole system. All subsequent procedures involve the synthesis of a 3-arylquinazoline-4(3H)-one derivative, which is then cyclized to give the indolo[2,1- $b]$ quinazoline moiety.

Potewar et al. initiated a two-step synthesis of tryptanthrin by preparation of the quinazolinone compound (41, Scheme 13), ${ }^{62}$ which was achieved by the condensation of anthranilic acid (15) with methyl anthranilate (32) in the presence of triethyl orthoformate (40). 
Deprotonation of $\mathbf{4 1}$ with LDA led to the intermediary anion $\mathbf{4 2}$ which then cyclized to give tryptanthrin in $54 \%$ over two steps.<smiles>CCOC(OCC)OCC</smiles>

15
40
32
42<smiles>COC(=O)c1ccccc1-n1c(Cl)nc2ccccc2c1=O</smiles><smiles>COC(=O)c1ccccc1-n1cnc2ccccc2c1=O</smiles>

41

\section{Scheme 13}

Lygin and de Meijere have offered a one-pot variant of the preceding approach (Scheme 14) and used isocyanide 43 as the starting material. ${ }^{63}$ Lithiation of $\mathbf{4 3}$ followed by addition of isocyanate $\mathbf{4 4}$ gave the same intermediary anion $\mathbf{4 2}$ as above, which formed tryptanthrin in a yield greater than $80 \%$.<smiles>COC(=O)c1ccccc1-n1c(Cl)nc2ccccc2c1=O</smiles>

\section{Scheme 14}

Bowman et al. used a different method with a related starting material for the cyclization step. ${ }^{64}$ In their approach the carboxylic acid 45 was converted into the phenylselenium compound 46, which was then subjected to ultraviolet light leading to the acyl radical 47. 
Although the yield is poor, this may be one of the first examples of a 5-exo acyl radical cyclization onto a heterocycle.<smiles>O=C(O)c1ccccc1-n1cnc2ccccc2c1=O</smiles>

45

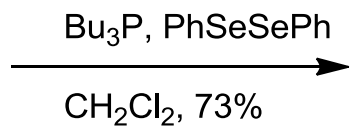<smiles>O=C([SeH]c1ccccc1)c1ccccc1-n1cnc2ccccc2c1=O</smiles>

46

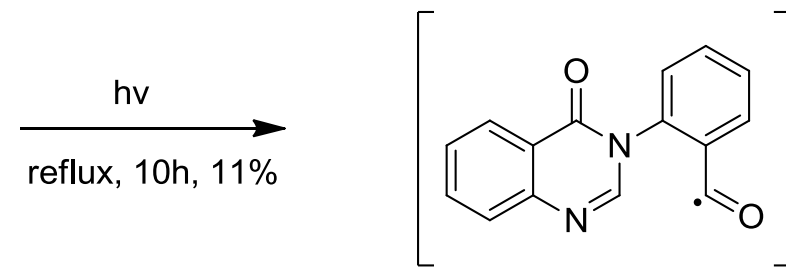

47<smiles>CC(C)C</smiles>

1

\section{Scheme 15}

Staskun and Wolfe described a protocol that is based on the observation that the 2-methyl group in 48 (Scheme 16) is sufficiently acidic to be deprotonated with sodium amide. ${ }^{59}$ Both 2chloro and 3-chloro derivatives reacted to give 32. In situ air oxidation of this intermediate produced tryptanthrin in approximately $80 \%$ yield. Since the yield was independent of the position (2- or 3-) of the chlorine substituent the authors proposed the formation of the benzyne intermediate $\mathbf{4 9}$ as a possible mechanistic step for this reaction.

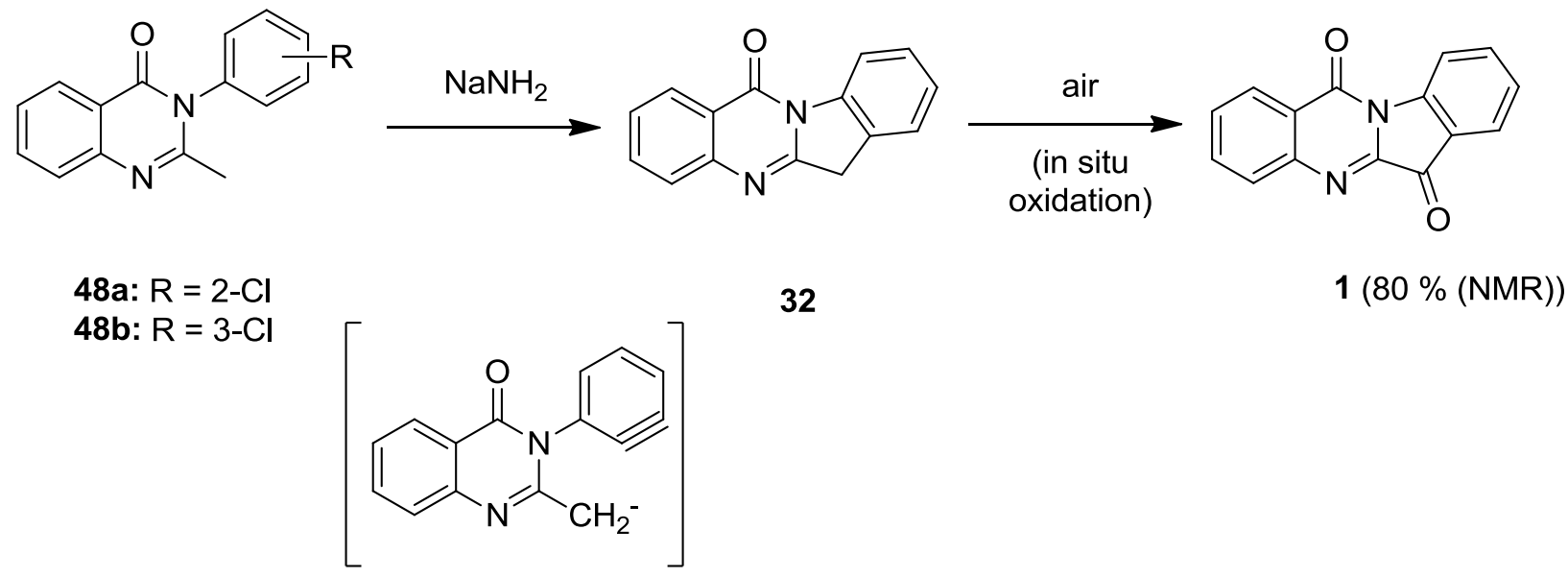

Scheme 16 


\section{Selected reactions of tryptanthrin and its derivatives}

\subsection{Aromatic substitution reactions}

Although tryptanthrin compounds with substituents attached to the aromatic rings are usually obtained by the reaction of substituted isatoic anhydrides and isatins ${ }^{6-8,25,34-37,40,41,45}$, selected tryptanthrin compounds have been synthesized by aromatic substitution reactions.

3.1.1 Electrophilic aromatic substitution. The 2- and 8-positions of tryptanthrin are susceptible towards electrophilic aromatic substitution. Dinitration of tryptanthrin has been accomplished using an excess of a sulfonitric mixture at $40^{\circ} \mathrm{C}$ generating 2,8-dinitrotryptanthrin (50) in excellent yield (Scheme 17). ${ }^{8}$<smiles>O=C1c2ccccc2-n2c1nc1ccccc1c2=O</smiles>

1

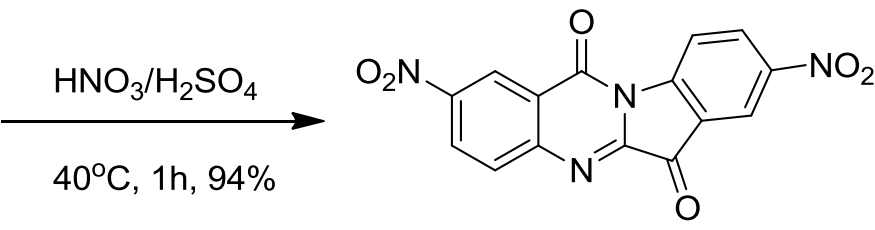

50

\section{Scheme 17}

The nitration of tryptanthrin has been shown to occur stepwise with the 8-position of tryptanthrin being more reactive than the 2-position. ${ }^{6}$ At $0{ }^{\circ} \mathrm{C}$, the addition of one equivalent of nitric acid selectively forms only 8-nitrotryptanthrin (51).<smiles>O=C1c2ccccc2-n2c1nc1ccccc1c2=O</smiles>

1

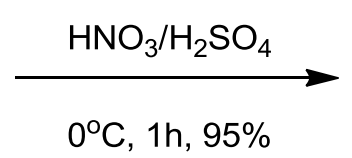

$0^{\circ} \mathrm{C}, 1 \mathrm{~h}, 95 \%$<smiles>O=C1c2cc([N+](=O)[O-])ccc2-n2c1nc1ccccc1c2=O</smiles>

51

\section{Scheme 18}

3.1.2. Nucleophilic aromatic substitution. The substitution of amino groups onto the aromatic rings has been investigated by Baker and Mitscher (Scheme 19). ${ }^{65}$ The synthesis of a series of piperazine substituted tryptanthrin compounds has been achieved by nucleophilic aromatic substitution. These reactions have been found to be regioselective - halogens at the 8- or 10position do not undergo substitution. In the reaction of 3,8-difluorotryptanthrin (52), with 1methylpiperazine (53) as the nucleophile, the nucleophilic aromatic substitution selectively occurred at the 3 -position to give the derivative $\mathbf{5 4} .^{65}$ 
<smiles>O=C1c2cc(F)ccc2-n2c1nc1cc(F)ccc1c2=O</smiles>

52

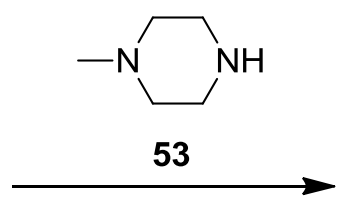

NMP $, 70^{\circ} \mathrm{C}, 1 \mathrm{~h}, 60 \%$<smiles>CN1CCN(c2ccc3c(=O)n4c(nc3c2)C(=O)c2cc(F)ccc2-4)CC1</smiles>

54

\section{Scheme 19}

\subsection{Reaction involving the carbonyl groups}

3.2.1 Hydrolysis. In the presence of aqueous sodium hydroxide tryptanthrin has been shown to undergo hydrolysis to yield 2-(2-aminobenzamido)benzoic acid (55, Scheme 20) ${ }^{66}$ as final product. The hydrolysis appeared to proceed stepwise. Initially, the 6-keto group underwent nucleophilic attack by the hydroxide resulting in the cleavage of the carbon-carbon bond between carbons 5 a and 6 to give the intermediate 45. Further degradation of the pyrimidine ring yielded the hydrolysis product $\mathbf{5 5}$ under a loss of formic acid.

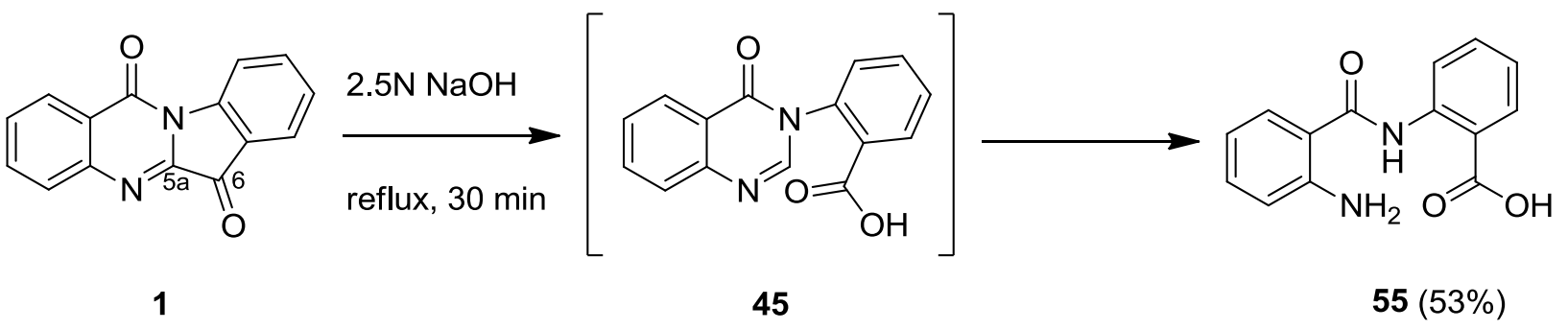

\section{Scheme 20}

3.2.2. Reduction. Extensive work has been performed by Bergman et al. to explore the chemical behavior of tryptanthrin under reducing conditions. The reduction of tryptanthrin with sodium triacetoxyhydroborate stereoselectively resulted in compound $\mathbf{5 6}$ (Scheme 21) which can be dehydrated to form $\mathbf{3 2} \cdot{ }^{58,67}$ As indicated above compound $\mathbf{3 2}$ has been observed to be unstable in the presence of air and is easily oxidized back to tryptanthrin.<smiles>O=C1c2ccccc2-n2c1nc1ccccc1c2=O</smiles>

1

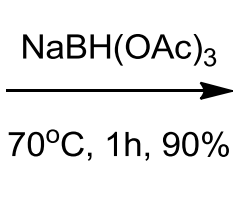

$70^{\circ} \mathrm{C}, 1 \mathrm{~h}, 90 \%$<smiles>O=C1c2ccccc2NC2(O)c3ccccc3[C@@H](O)[C@H]12</smiles>

56

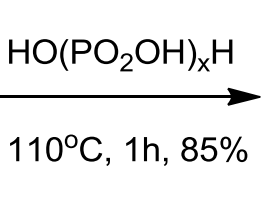<smiles>O=c1c2ccccc2nc2n1-c1ccccc1C2</smiles>

32

\section{Scheme 21}


Treatment of tryptanthrin with hypophosphorous acid resulted in a reductive dimerization to yield compound 57 (Scheme 22) ${ }^{58} 57$ readily underwent dehydrogenation to yield the violet dimer 58.

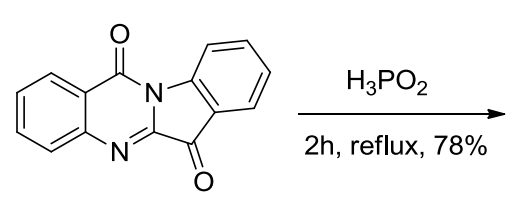

1

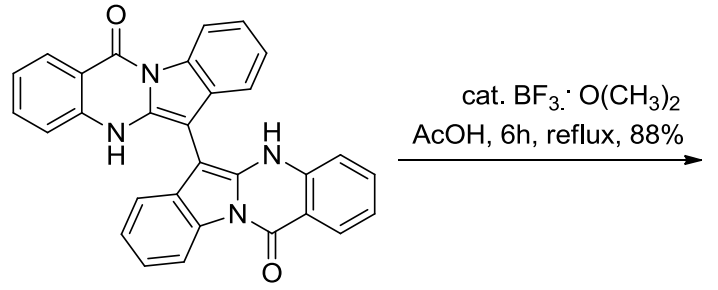

57

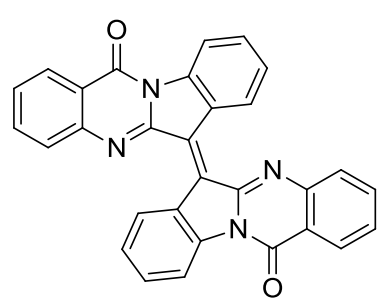

58

\section{Scheme 22}

Reduction of tryptanthrin with lithium aluminum hydride led to compound $\mathbf{5 9}$ (Scheme 23), which was characterized as the diacetyl ester $60 .{ }^{58}$ The structure of $\mathbf{6 0}$ has been confirmed by Xray crystallography. Alternatively, partial oxidation of $\mathbf{5 9}$ by manganese dioxide led to compound 61.68

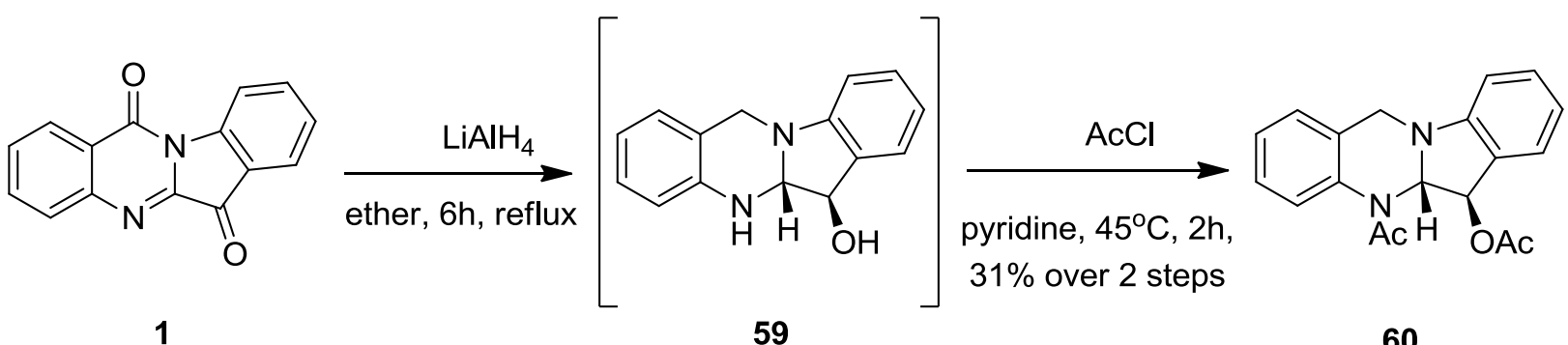

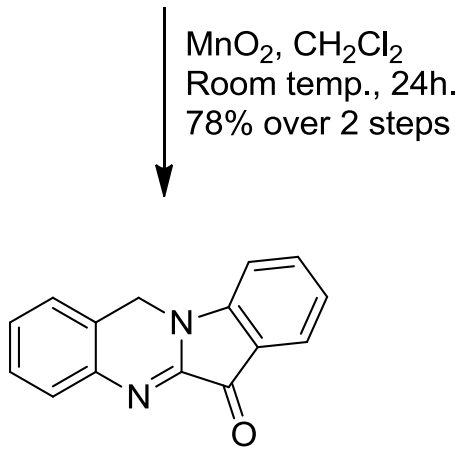

61

\section{Scheme 23}

3.2.3 Oxidation. Tryptanthrin and its ring substituted derivatives appear to be stable towards chemical oxidation agents including potassium permanganate ${ }^{10,29,61}$, chromium trioxide $^{56}$, 
oxone $^{55}$ and ozone. ${ }^{46}$ Ring oxidation has been observed in many biological systems and Lee $e t$ al. concluded that 8-hydroxytryptanthrin (62, Scheme 24) - along with an unidentified dihydroxy tryptanthrin derivative - is a phase I metabolite of tryptanthrin in an in vitro rat liver model. ${ }^{38}$<smiles></smiles>

1

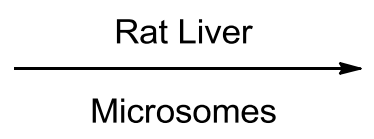

Microsomes<smiles>O=C1c2cc(O)ccc2-n2c1nc1ccccc1c2=O</smiles>

62

\section{Scheme 24}

3.2.4. Reactions with nitrogen nucleophiles. Tryptanthrin and its substituted derivatives react with nitrogen nucleophiles including hydrazines, hydroxyl amine and alkoxy amines to give the corresponding 6-hydrazones ${ }^{\text {7, 40, 60, } 66}$ and 6-oximes. ${ }^{6}$ In particular 6-oximes and 6-imines have received particular attention due to their biological properties. Suitably substituted 6-oxime esters and ethers of tryptanthrin have been shown to increase bioavailability. The oxime ether 64 has been shown to possess a bioavailability of $76 \%$ at a $20 \mathrm{mg} / \mathrm{kg}$ dose in mice. ${ }^{6}$<smiles>O=C1c2ccccc2-n2c1nc1ccccc1c2=O</smiles>

1

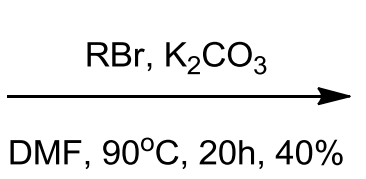

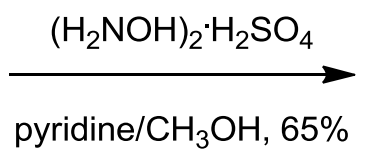<smiles>O=[N+]=C1c2ccccc2-n2c1nc1ccccc1c2=O</smiles>

64<smiles>N=C1c2ccccc2-n2c1nc1ccccc1c2=O</smiles>

63<smiles>[R]=CCCN(C)C</smiles>

\section{Scheme 25}

The single step synthesis of 6-aryl imines from the corresponding tryptanthrin compounds has been reported with low to moderate yields. ${ }^{7}$ An alternative procedure involves the reaction of isatin-3-imine compounds including isatin imine $\mathbf{6 5}$ and isatoic anhydride (15) in the presence of a catalytic amount of $\mathrm{KF}-\mathrm{Al}_{2} \mathrm{O}_{3}$ under microwave conditions as shown in Scheme $26 .{ }^{69}$ 
<smiles>O=c1[nH]c2ccccc2c(=O)o1</smiles>

15<smiles>O=C1Nc2ccccc2/C1=N\c1ccccc1</smiles>

65

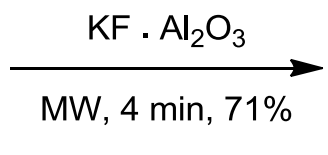<smiles>O=c1c2ccccc2nc2n1-c1ccccc1/C2=N/c1ccccc1</smiles>

66

\section{Scheme 26}

3.2.5 Reactions with CH-acidic compounds. Racemic phaitanthrin A (4) was obtained from tryptanthrin by treatment with acetone in the presence of diethylamine (Scheme 27). ${ }^{22}$ Acetone serves both as solvent and as a reactant. If acetone is replaced by 2-decanone, the reaction adds selectively at the 1-methyl group. The cyclopentanone substituted derivative was found to be unstable.<smiles>O=C1c2ccccc2-n2c1nc1ccccc1c2=O</smiles>

1

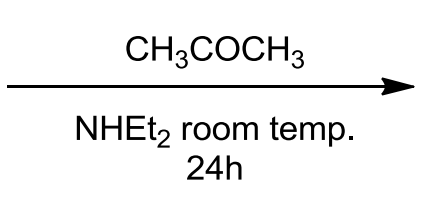

When a suspension of tryptanthrin (1) in acetone is treated with hydrazine the azine $\mathbf{6 7}$ is obtained (Scheme 28) ${ }^{70}$. When crystallized this compound adopts Z-configuration.<smiles>O=C1c2ccccc2-n2c1nc1ccccc1c2=O</smiles>

1
, reflux 0.5 h, $72 \%$

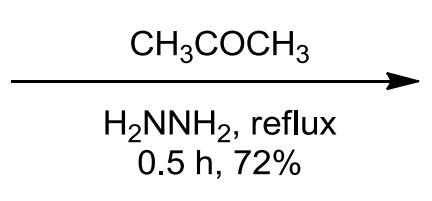

67<smiles>CC(C)=N/N=C(/C)CC1(O)c2ccccc2-n2c1nc1ccccc1c2=O</smiles>

\section{Scheme 28}

Guentner et al. investigated a series of tryptanthrin derivatives as potential dyes and pigments. ${ }^{7}$ Their work included the preparation of tryptanthrin derivatives with extended $\pi$ systems. In the reaction of tryptanthrin with 1,4-diacetylpiperazine-2,5-dione (68, Scheme 29) 
the bridged dimer of tryptanthrin (69) was isolated in excellent yield.<smiles>O=C1c2ccccc2-n2c1nc1ccccc1c2=O</smiles>

1<smiles>CC(=O)N1CC(=O)N(C(C)=O)CC1=O</smiles>

68

$\mathrm{NEt}_{3}, \mathrm{DMF}, 3 \mathrm{~h}$ reflux, $86 \%$<smiles>O=c1[nH]c(=c2c3ccccc3n3c(=O)c4ccccc4nc23)c(=c2c3ccccc3n3c(=O)c4ccccc4nc23)[nH]c1=O</smiles>

69

\section{Scheme 29}

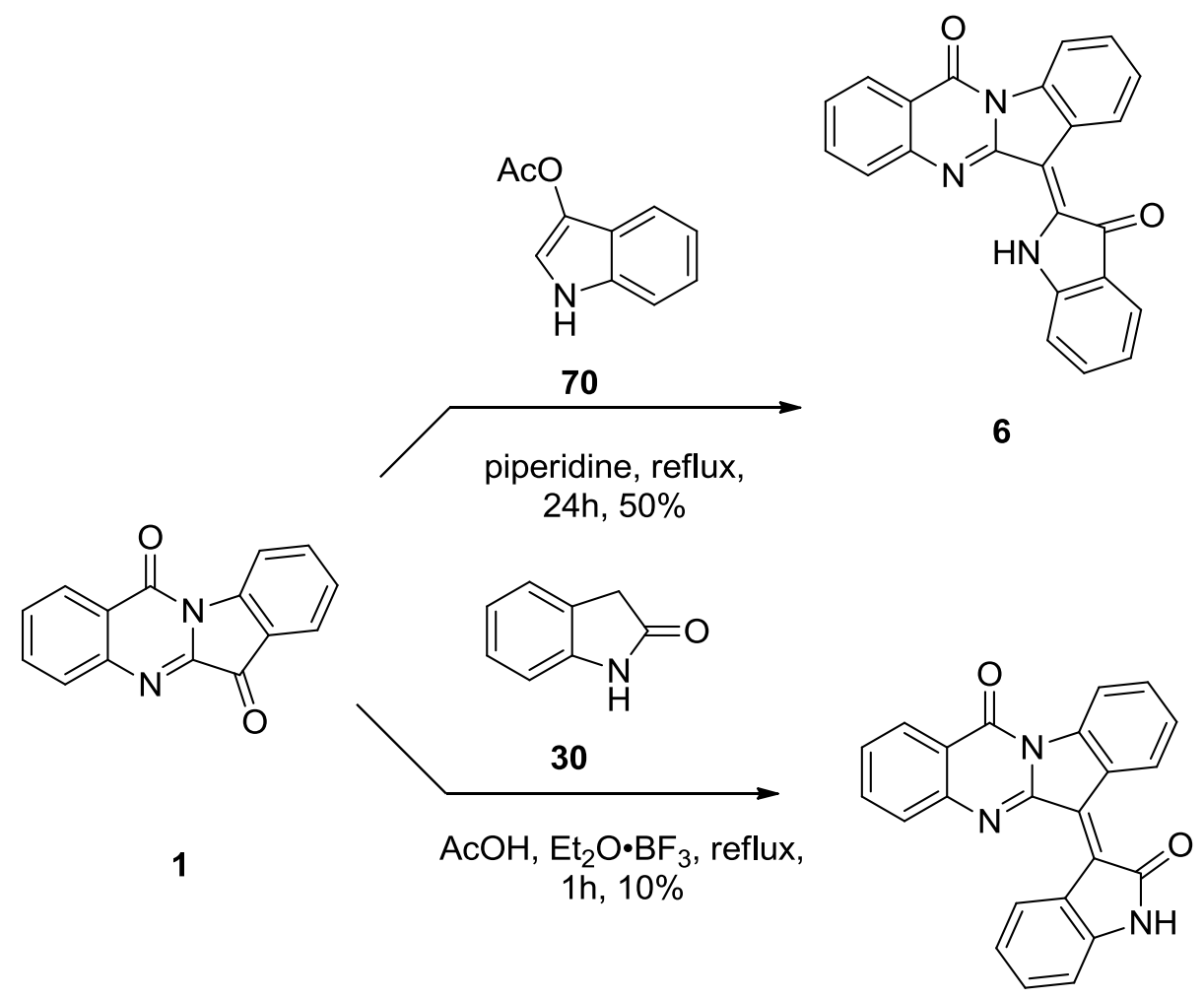

71

\section{Scheme 30}

The synthesis of candidine (6) can be achieved by treatment of tryptanthrin with indoxyl acetate (70, Scheme 30). Under the reaction conditions shown a mild hydrolysis occurs. ${ }^{32}$ For 
this synthesis N,O-diacetylindoxyl has also been used. ${ }^{29}$ Reaction with oxindole gave to candidine isomeric compound $\mathbf{7 1} .^{32}$

Tryptanthrin reacts with malonitrile to form dicyanomethylene derivative $\mathbf{7 2} .^{32,34,42}$ This derivative has been also obtained in one-pot microwave reaction. ${ }^{42}$<smiles>O=C1c2ccccc2-n2c1nc1ccccc1c2=O</smiles>

1

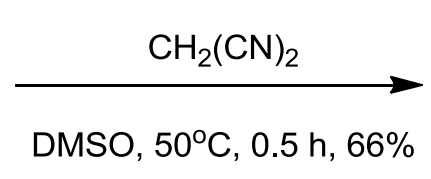

DMSO, $50^{\circ} \mathrm{C}, 0.5 \mathrm{~h}, 66 \%$<smiles>N#CC(C#N)=c1c2ccccc2n2c(=O)c3ccccc3nc12</smiles>

72

\section{Scheme 31}

Grandolini et al. showed that tryptanthrin undergoes a Darzens reaction to yield compound 73 (Scheme 32). ${ }^{40}$ Nucleophilic ring opening then the resulted in the chlorohydrin 74.<smiles>O=C1c2ccccc2-n2c1nc1ccccc1c2=O</smiles>

1

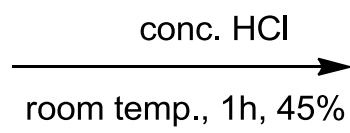

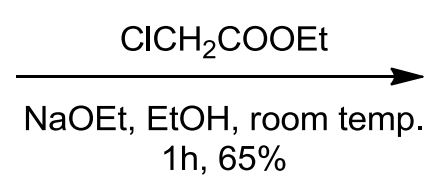

$1 \mathrm{~h}, 65 \%$<smiles>CCOC(O)C(O)C1(c2ccccc2)n2c(nc3ccccc3c2=O)C1(O)OCC</smiles>

74<smiles>CCOC(=O)C1OC12c1ccccc1-n1c2nc2ccccc2c1=O</smiles>

73

\section{Scheme 32}

3.2.6 Reactions with Grignard reagents. Tryptanthrin and 8-bromotryptanthrin (75) add Grignard reagents to the 6-carbonyl group in moderate yields. ${ }^{71}$ Thus the reaction of $\mathbf{7 5}$ with methylmagnesium bromide led to the tertiary alcohol $\mathbf{7 6}$ as the only product in $64 \%$ yield (Scheme 33). 
<smiles>O=C1c2cc(Br)ccc2-n2c1nc1ccccc1c2=O</smiles>

75

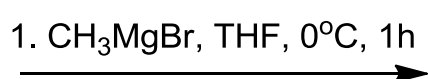

2. aq. $\mathrm{NH}_{4} \mathrm{Cl}, 64 \%$<smiles>CC1(O)c2cc(Br)ccc2-n2c1nc1ccccc1c2=O</smiles>

76

\section{Scheme 33}

3.2.7 Synthesis of 6-spiro derivatives. Azizian et al. have extensively studied the synthesis of tryptanthrin 6-spiro derivatives. This group investigated the synthesis of 6-spiro- $\gamma$-lactone ${ }^{72}, 6$ spiro- $\gamma$-iminolactone ${ }^{73}$, 6-spiro-[1,2,4] oxadiazoline $^{74}$ and 6-spiro[1,2,4] triazoline $^{75}$ derivatives of tryptanthrin. In a one-pot reaction the tryptanthrin-6-imine $\mathbf{6 6}^{69}$ reacts with nitrilimine 77 prepared in situ from the corresponding hydrazonyl chloride $\mathbf{7 8}$ - in a dipolar 1,3-cycloaddition to give the spiro-1,2,4-triazole compound 79 in excellent yield (Scheme 34). ${ }^{75}$

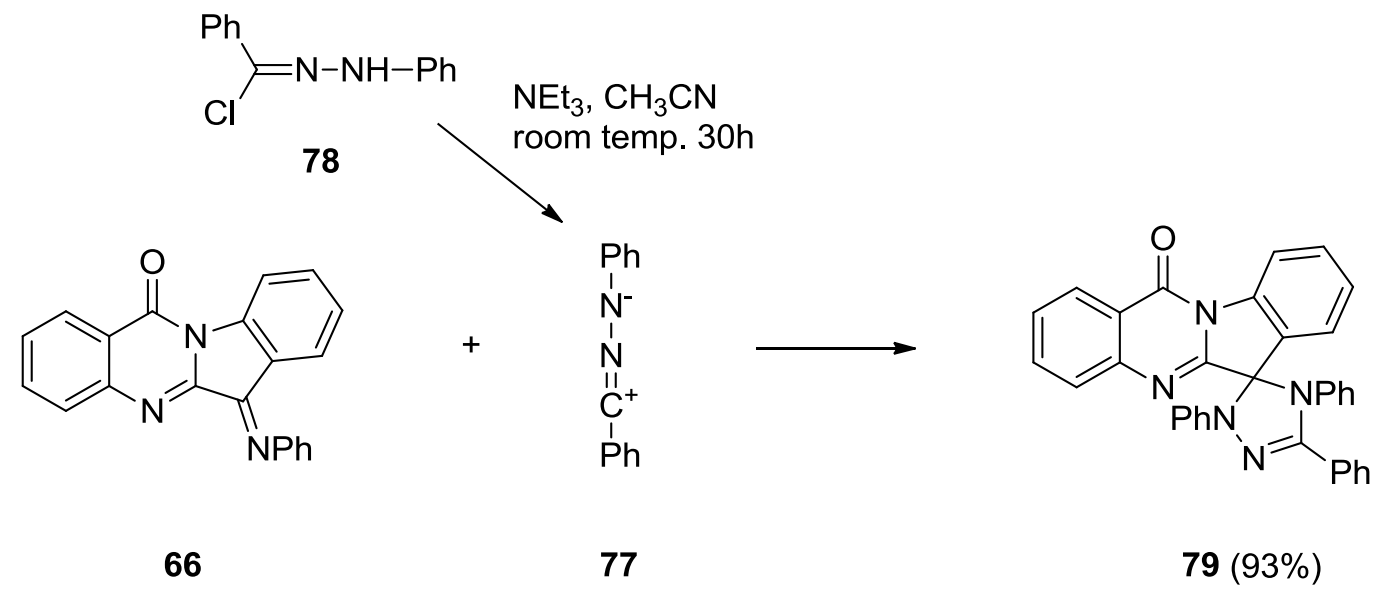

\section{Scheme 34}

\section{References}

1. Schindler, F.; Zaehner, H. Arch. Mikrobiol. 1971, 79, 187.

2. For an earlier review see: Witt, A.; Bergman, J. Curr. Org. Chem. 2003, 7, 659.

3. (a) Honda, G.; Tabata, M.; Tsuda, M. Planta Med. 1979, 37, 172. (b) Mitscher, L. A.; Baker, W. Med. Res. Rev. 1998, 18, 363. (c) Kataoka, M.; Hirata, K.; Kunikata, T.; Ushio, S.; Iwaki, K.; Ohashi, K.; Ikeda, M.; Kurimoto, M. J. Gastroenterol. 2001, 36, 5. (d) Bandekar, P. P.; Roopnarine, K. A.; Parekh, V. J.; Mitchell, T. R.; Novak, M. J.; Sinden, R. R. J. Med. Chem. 2010, 53, 3558. 
4. (a) Bhattacharjee, A. K.; Skanchy, D. J.; Jennings, B.; Hudson, T. H.; Brendle, J. J.; Werbovetz, K. A. Bioorg. Med. Chem. 2002, 10, 1979. (b) Scovill, J.; Blank, E.; Konnick, M.; Nenortas, E.; Shapiro, T. Antimicrob. Agents Chemother. 2002, 46, 882. (c) Bhattacharjee, A. K.; Hartell, M. G.; Nichols, D. A.; Hicks, R. P.; Stanton, B.; Van Hamont, J. E.; Milhous, W. K. Eur. J. Med. Chem. 2004, 39, 59. (d) Pitzer, K. K.; Scovill, J. P.; Kyle, D. E.; Gerena, L. PCT Int. Appl. WO0018769A2, 2000. (e) Krivogorsky, B.; Grundt, P.; Yolken, R.; Jones-Brando, L. Antimicrob. Agents Chemother. 2008, 52, 4466. (f) Hicks, R. P.; Nichols, D. A.; DiTusa, C. A.; Sullivan, D. J.; Hartell, M. G.; Koser, B. W.; Bhattacharjee, A. K. Internet Electronic J Mol. Des. 2005, 4, 751.

5. (a) Motoki, T.; Takami, Y.; Yagi, Y.; Tai, A.; Yamamoto, I.; Gohda, E. Biol. Pharm. Bull. 2005, 28, 260. (b) Yu, S.-T.; Chen, T.-M.; Chern, J.-W.; Tseng, S.-Y.; Chen, Y.-H. AntiCancer Drugs 2009, 20, 382.

6. Sharma, V. M.; Prasanna, P.; Adi Seshu, K. V.; Renuka, B.; Laxman Rao, C. V.; Sunil Kumar, G.; Narasimhulu, C. P.; Aravind Babu, P.; Puranik, R. C.; Subramanyam, D.; Venkateswarlu, A.; Rajagopal, S.; Kumar, K. B. S.; Rao, C. S.; Mamidi, N. V. S. R.; Deevi, D. S.; Ajaykumar, R.; Rajagopalan, R. Bioorg. Med. Chem. Lett. 2002, 12, 2303.

7. Guentner, A.; Seybold, G.; Wagenblast, G. Ger. Offen. DE4114990A1, 1992.

8. Kawaguchi, H.; Mizuta, Y.; Sugai, F.; Saito, S.; Matsumoto, S.; Fukami, T.; Yamazato, I.; Uegaito, H.; Tanaka, Y., et al. Eur. Pat. Appl. EP0718298A1, 1996.

9. (a) Gruznev, D. V.; Chubenko, D. N.; Zotov, A. V.; Saranin, A. A. J. Phys. Chem. C 2010, 114, 14489. (b) Novak, M. J.; Baum, J. C.; Buhrow, J. W.; Olson, J. A. Surf. Sci. 2006, 600, L269.

10. O'Neill, C. Chem. News 1892, 65, 124.

11. Seidel, P. BASF, Ludwigshafen 1938; Tryptanthrin may have been synthesized as early as 1822: Dumas. Journ. Pharm 1822, VIII, 377; Seidel, P. BASF, Ludwigshafen 1938 and references cited therein.

12. Friedländer, P.; Roschdestwensky, N. Chem. Ber. 1915, 48, 1841.

13. (a) Brufani, M.; Fedeli, W.; Mazza, F.; Gerhard, A.; Keller-Schierlein, W. Experientia 1971, 27, 1249. (b) Fedeli, W.; Mazza, F. J. Chem. Soc., Perkin Trans. 2 1974, 1621.

14. Honda, G.; Tosirisuk, V.; Tabata, M. Planta Med. 1980, 38, 275.

15. (a) Li, Q.; Jin, J.; Chong, M.; Song, Z. Zhongcaoyao 1983, 14, 440. (b) Seifert, K.; Unger, W. Z. Naturforsch., C: Biosci. 1994, 49, 44. (c) Wu, X. Y.; Liu, Y. H.; Sheng, W. Y.; Sun, J.; Qin, G. W. Planta Med. 1997, 63, 55. (d) Li, B.; Chen, W.; Zheng, S.; Yang, G.; Qiao, C. Yaoxue Xuebao 2000, 35, 508. (e) Danz, H.; Stoyanova, S.; Thomet Olivier, A. R.; Simon, H.-U.; Dannhardt, G.; Ulbrich, H.; Hamburger, M. Planta Med. 2002, 68, 875. (f) Ruan, J.L.; Zou, J.-H.; Cai, Y.-L. Zhongguo Zhong Yao Za Zhi 2005, 30, 1525. (g) Mohn, T.; Plitzko, I.; Hamburger, M. Phytochemistry (Elsevier) 2009, 70, 924.

16. Hashimoto, T.; Aga, H.; Chaen, H.; Fukuda, S.; Kurimoto, M. Nat. Med. (Tokyo) 1999, 53, 27. 
17. (a) Honda, G.; Tabata, M. Planta Med. 1979, 36, 85. (b) Mitscher, L. A.; Baker, W. R. Pure Appl. Chem. 1998, 70, 365. (c) Liau, B.-C.; Jong, T.-T.; Lee, M.-R.; Chen, S.-S. J. Pharm. Biomed. Anal. 2007, 43, 346.

18. Lin, Y.-K.; Leu, Y.-L.; Huang, T.-H.; Wu, Y.-H.; Chung, P.-J.; Su Pang, J.-H.; Hwang, T.-L. J. Ethnopharmacol. 2009, 125, 51.

19. George, V.; Koshy, A. S.; Singh, O. V.; Nayar, M. N. S.; Pushpangadan, P. Fitoterapia 1996, 67, 553.

20. Sen, A. K.; Mahato, S. B.; Dutta, N. L. Tetrahedron Lett. 1974, 15, 609.

21. Bergman, J.; Egestad, B.; Lindstroem, J. O. Tetrahedron Lett. 1977, 2625.

22. Jao, C. W.; Lin, W. C.; Wu, Y. T.; Wu, P. L. J. Nat. Prod. 2008, 71, 1275.

23. Yoshikawa, M.; Murakami, T.; Kishi, A.; Sakurama, T.; Matsuda, H.; Nomura, M.; Matsuda, H.; Kubo, M. Chem. Pharm. Bull. 1998, 46, 886.

24. Hosoe, T.; Nozawa, K.; Kawahara, N.; Fukushima, K.; Nishimura, K.; Miyaji, M.; Kawai, K.-i. Mycopathologia 2000, 146, 9.

25. Jarrah, M. Y.; Thaller, V. J. Chem. Res., Synop. 1980, 186.

26. (a) Shaaban, M.; Maskey, R. P.; Wagner-Döbler, I.; Laatsch, H. J. Nat. Prod. 2002, 65, 1660.

(b) Wagner-Döbler, I.; Rheims, H.; Felske, A.; El-Ghezal, A.; Flade-Schroeder, D.; Laatsch, H.; Lang, S.; Pukall, R.; Tindall, B. J. Int. J. Syst. Evol. Microbiol. 2004, 54, 1177.

27. Rasmussen, L. E. L.; Lee, T. D.; Daves, D., Jr.; Schmidt, M. J. J. Chem. Ecol. 1993, 19, 2115.

28. Caspers, B.; Franke, S.; Voigt, C. C. The Wing-Sac Odour of Male Greater Sac-Winged Bats Saccopteryx bilineata (Emballonuridae) as a Composite Trait: Seasonal and Individual Differences; Springer: Liverpool, 2008;

29. Zou, J.; Huang, L. Acta Pharm. Sinica 1985, 20, 45.

30. Peng, Y.; Zhang, L.; Song, H.; Pan, W.; Sun, Y. Zhongguo Yaowu Huaxue Zazhi 2005, 15, 371.

31. Laatsch, H.; Ludwig-Koehn, H. Liebigs Ann. Chem. 1986, 1847.

32. Bergman, J.; Tilstam, U. Tetrahedron 1985, 41, 2883.

33. Utkina, N. K.; Denisenko, V. A. Tetrahedron Lett. 2007, 48, 4445.

34. Yu, S.-t.; Chern, J.-w.; Chen, T.-m.; Chiu, Y.-f.; Chen, H.-t.; Chen, Y.-h. Acta Pharmacol. Sin. 2010, 31, 259.

35. Mason, J. J.; Janosik, T.; Bergman, J. Synthesis 2009, 3642.

36. Bergman, J.; Lindstroem, J. O.; Tilstam, U. Tetrahedron 1985, 41, 2879.

37. (a) Mitscher, L. A.; Wong, W.-C.; DeMeulenaere, T.; Sulko, J.; Drake, S. Heterocycles 1981, 15, 1017. (b) Valiante, N. PCT Int. Appl. WO2004064759A2, 2004.

38. Lee, S. K.; Kim, G. H.; Kim, D. H.; Kim, D. H.; Jahng, Y.; Jeong, T. C. Biol. Pharm. Bull. 2007, 30, 1991.

39. Gilman, R. E.; Novak, M. J.; Baum, J. C.; Olson, J. A. J. Phys. Chem. C 2008, 112, 14545.

40. Grandolini, G.; Ambrogi, V.; Perioli, L.; Giannangeli, M.; Jovicevic, L.; Rossi, V. Farmaco 1997, 52, 679 . 
41. Liu, J.; Wang, C.; Liu, Z. Chin. Pat. CN101177428A, 2008.

42. Azizian, J.; Mohammadizadeh, M. R.; Zomorodbakhsh, S.; Mohammadi, A. A.; Karimi, A. R. Arkivoc 2007, (xv), 24.

43. Kumar, A.; Tripathi, V. D.; Kumar, P. Green Chem. 2011, 13, 51.

44. Chen, G. S.; Bhagwat, B. V.; Liao, P.-Y.; Chen, H.-T.; Lin, S.-B.; Chern, J.-W. Bioorg. Med. Chem. Lett. 2007, 17, 1769.

45. Akazome, M.; Kondo, T.; Watanabe, Y. J. Org. Chem. 1993, 58, 310.

46. Matsui, M.; Morita, M.; Shibata, K.; Takase, Y. Nippon Kagaku Kaishi 1982, 1268.

47. Machemer, H. Ber. Dtsch. Chem. Ges. B 1930, 63B, 1341.

48. Jahng, K. C.; Kim, S. I.; Kim, D. H.; Seo, C. S.; Son, J.-K.; Lee, S. H.; Lee, E. S.; Jahng, Y. Chem. Pharm. Bull. 2008, 56, 607.

49. Eguchi, S.; Takeuchi, H.; Matsushita, Y. Heterocycles 1992, 33, 153.

50. Grimshaw, J.; Begley, W. J. Synthesis 1974, 496.

51. (a) Moskovkina, T. V. Russ. J. Org. Chem. 1997, 33, 125. (b) Moskovkina, T.; Kalinovskii, A.; Makhan'kov, V. Russian Journal of Organic Chemistry 2012, 48, 123.

52. Oberthür, C.; Hoffmann, B.; Hamburger, M. Die Pharmazie 2002, 57, 586.

53. (a) Becker, J. Y.; Shakkour, E. Tetrahedron 1994, 50, 12773. (b) Batanero, B.; Barba, F. Tetrahedron Lett. 2006, 47, 8201.

54. Karpf, H.; Junek, H. Tetrahedron Lett. 1978, 3007.

55. Nelson, A.; Grundt, P. unpublished results.

56. Bird, C. W. Tetrahedron 1963, 19, 901.

57. (a) Son, J. K.; Park, J. G.; Jahng, Y. Heterocycl. Commun. 2003, 9, 621. (b) Lee, E. S.; Park, J.-G.; Jahng, Y. Tetrahedron Lett. 2003, 44, 1883.

58. Bergman, J.; Tilstam, U.; Toernroos, K. W. J. Chem. Soc., Perkin Trans. 1 1987, 519.

59. Staskun, B.; Wolfe, J. F. S. Afr. J. Chem. 1992, 45, 5.

60. Kikumoto, R.; Kobayashi, T. Tetrahedron 1966, 22, 3337.

61. Zeide, O. A.; Chelintsev, G. V. Zh. Obshch. Khim. 1937, 7, 2318.

62. Potewar, T. M.; Ingale, S. A.; Srinivasan, K. V. Arkivoc 2008, (xiv), 100.

63. Lygin, A. V.; de Meijere, A. Org. Lett. 2009, 11, 389.

64. Bowman, W. R.; Elsegood, M. R. J.; Stein, T.; Weaver, G. W. Org. Biomol. Chem. 2007, 5, 103.

65. Baker, W. R.; Mitscher, L. A. PCT Int. Appl. WO9513807A1, 1995.

66. Butler, K.; Partridge, M. W.; Waite, J. A. J. Chem. Soc. 1960, 4970.

67. For the synthesis of the tautomer of 32 see: Xia, Z.; Wang, K.; Zheng, J.; Ma, Z.; Jiang, Z.; Wang, X.; Lv, X. Org. Biomol. Chem. 2012, 10, 1602.

68. For an alternative route to obtain 61 see: Baiocchi, L.; Giannangeli, M.; Rossi, V.; Ambrogi, V.; Grandolini, G.; Perioli, L. Farmaco 1993, 48, 487.

69. Azizian, J.; Mohammadi, A. A.; Ardakani, F.; Karimi, A. R.; Mohammadizadeh, M. R. Heterocycles 2004, 63, 791. 
70. Rodstein, M. E.; Steffen, P. D.; Krivogorsky, B.; Grundt, P. Acta Crystallogr., Sect. E: Struct. Rep. Online 2011, E67, o2695.

71. Douglas, K. A.; Grundt, P. unpublished results.

72. Azizian, J.; Karimi, A. R.; Arefrad, H.; Mohammadi, A. A.; Mohammadizadeh, M. R. Monatshefte für Chemie 2004, 135, 729.

73. (a) Azizian, J.; Karimi, A. R.; Mohammadi, A. A. Synth. Commun. 2003, 33, 387. (b) Azizian, J.; Karimi, A. R.; Mohammadi, A. A.; Mohammadizadeh, M. R. Heterocycles 2004, $63,2225$.

74. Azizian, J.; Madani, M.; Souzangarzadeh, S. Synth. Commun. 2005, 35, 765.

75. Azizian, J.; Mohammadizadeh, M. R.; Javadi, M.; Mohammadi, A. A.; Karimi, A. R. J. Chem. Res. 2004, 125.

\section{Authors' Biographies}

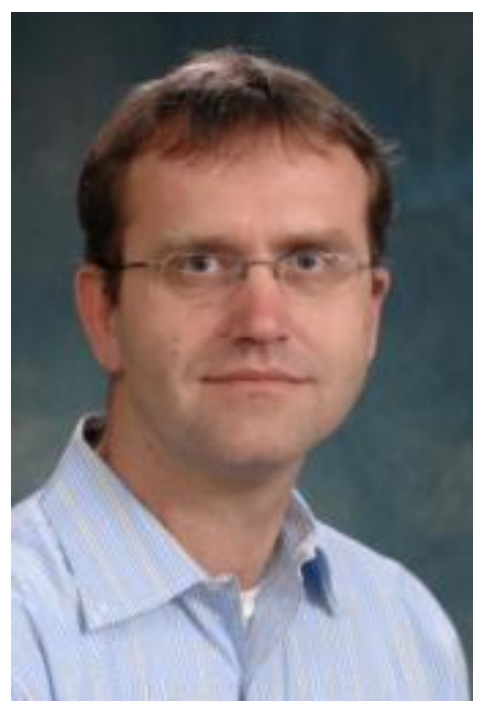

Peter Grundt received in his PhD degree from the Universität GH Duisburg, Germany in 1998. He pursued postdoctoral studies in the UK (University of Bristol and University of Bath) and at the National Institute of Drug Abuse, Baltimore, and USA. In 2007, he joined the faculty of the University of Minnesota Duluth. His current research interests include heterocyclic chemistry and natural products as inhibitors of the parasite Toxoplasma gondii. 


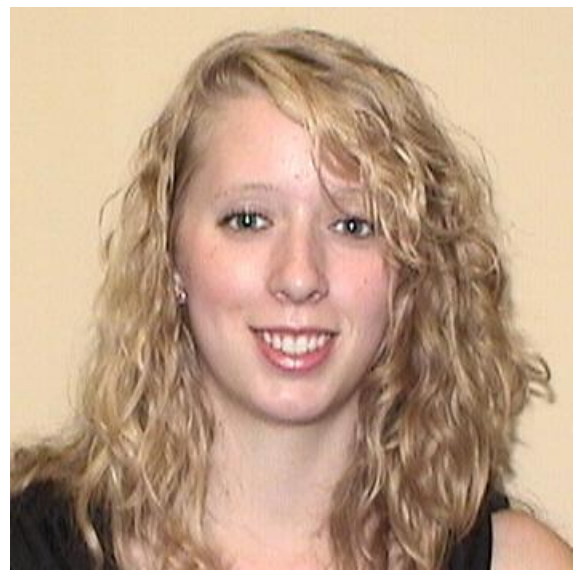

Ashli M. Tucker received her BA in chemistry from the University of Minnesota Morris. She pursued studies for her master's degree in chemistry at the University of Minnesota Duluth. Currently she works for The Minneapolis Medical Research Foundation. 